\title{
A Zoom on Dermoscopic Polymorphous Vascular Pattern Observed in Common Benign Cutaneous Tumors (Seborrheic Keratosis, Dermal/Congenital Nevi, Dermatofibroma, Viral Wart): A Multicentric, Observational Study
}

\author{
Sık Görülen Benign Deri Tümörlerinde (Seboreik Keratoz, \\ Dermal/Konjenital Nevus, Dermatofibroma, Viral Siğiller) Dermoskopik \\ Polimorföz Vasküler Patern: Çok Merkezli, Gözlemsel Çalışma
}

\author{
Omer Faruk ELMAS $\odot$, Murat CELiK $\odot$
}

Ethics Committee Approval: This study approved by the Ahi Evran University Ethical Committee for Ethical Studies (08 January 2019, 2019/01/08)

Conflict of interest: The authors declare that they have no conflict of interest.

Funding: None.

Informed Consent: Informed consent was taken from all participants.
Cite as: Elmas OF, Celik M. A Zoom on Dermoscopic Polymorphous Vascular Pattern Observed in Common Benign Cutaneous Tumors (Seborrheic Keratosis, Dermal/Congenital Nevi, Dermatofibroma, Viral Wart): A Multicentric, Observational Study. Medeniyet Med J. 2019;34:130-4

\begin{abstract}
Objective: The vascular patterns observed in dermoscopic examination are considered to be important diagnostic clues and many skin lesions show a characteristic vasculature. Polymorphous vascular pattern (PVP) is usually thought to indicate malignant cutaneous tumors. In this study, we aimed to investigate the frequency of dermoscopic PVP in common benign cutaneous tumors.

Methods: Histopathologically confirmed common benign cutaneous tumors collected from two different centers were included in the study. Dermoscopic images of all lesions were examined retrospectively and the lesions showing polymorphous vascular patterns were determined. Results: A total of 350 histopathologically confirmed benign cutaneous tumors were evaluated regarding the presence of PVP. Nine percent of dermal/congenital nevi $(n=9), 13 \%(n=13)$ of seborrheic keratoses and $5 \%$ of viral warts $(n=5)$ showed PVP. None of the dermatofibromas exhibited PVP.

Conclusion: Our study showed that PVP is not a very rare dermoscopic vascular pattern in benign skin tumors. We think that dermoscopic PVP alone should not be accepted as a sign of malignancy and should be evaluated in the context of the other present structural dermoscopic findings.
\end{abstract}

Keywords: Dermoscopy, polymorphous vessels, vascular structures

Öz

\begin{abstract}
Amaç: Dermoskopik muayene sırasında izlenen vasküler paternler, önemli tanısal ipuçları olarak kabul edilir ve birçok deri lezyonu karakteristik bir vasküler paterne sahiptir. Polimorf vasküler patern (PVP) sıklıkla, malign lezyonların vasküler paterni olarak değerlendirilmektedir. Bu çalışmada, sık görülen benign deri tümörlerinde dermoskopik PVP sıklığının araştırılması amaçlanmıştır. Metod: Bu çalıșmaya iki farklı merkezden toplanan, histopatolojik olarak doğrulanmıș olan sık görülen benign deri tümörleri dahil edilmiştir. Tüm lezyonların dermoskopik görüntüleri, retrospektif olarak incelenmiş ve polimorf vasküler patern gösteren lezyonlar belirlenmiştir.

Bulgular: Histopatolojik olarak tanının doğrulandığı toplamda 350 benign deri tümörü PVP varlığı açısından değerlendirilmiştir. Dermal/konjenital nevüslerin \%9'u, seboreik keratozların \%13'ü, viral siğillerin \%5'i PVP göstermiştir. Dermatofibroma olgularında PVP izlenmemiştir.

Sonuç: Çalışmamız, PVP'nin benign tümörlerde çok nadir rastlanılan bir vasküler patern olmadığını göstermiştir. Biz, dermoskopik PVP'nin tek başına bir malignite bulgusu olarak görülmemesi ve diğer yapısal dermoskopik bulgular bağlamında değerlendirilmesi gerektiğini düşünüyoruz.
\end{abstract}

Anahtar kelimeler: Dermoskopi, polimorf damar paterni, vasküler yapılar
Received: 22.03 .2019

Accepted: 08.05.2019

Online First: 10.06 .2019

Corresponding Author: O.F. Elmas

ORCID: 0000-0002-5474-6508

Ahi Evran University,

Faculty of Medicine,

Department of Dermatology, Kırşehir - Turkey

omerfarukmd@gmail.com

M. Celik

ORCID: 0000-0002-0798-1310

Kars Harakani State Hospital, Pathology Department, Kars, Turkey 
O.F. Elmas et al. A Zoom on Dermoscopic Polymorphous Vascular Pattern Observed in Common Benign Cutaneous Tumors (Seborrheic Keratosis, Dermal/Congenital Nevi, Dermatofibroma, Viral Wart): A Multicentric, Observational Study

\section{INTRODUCTION}

Dermoscopy is a noninvasive diagnostic method allowing detailed evaluation of the skin lesions and it has recently become an indispensable part of daily dermatology practice. Vascular patterns observed in dermoscopic examination are considered as important diagnostic clues and many lesions show a characteristic vasculature.

Polymorphous vascular pattern (PVP) is dermoscopically defined as the combination of two or more vascular structures ${ }^{1}$. This combination often includes serpentine (linear-irregular) and dotted vessels ${ }^{1}$. PVP is usually thought to indicate malignant cutaneous tumors, especially melanoma ${ }^{2}$. In this study, we aimed to investigate the frequency of this vascular pattern in benign cutaneous tumors.

\section{MATERIAL and METHODS}

The study was approved by the (08 January 2019, 2019/01/08). Informed consent was taken from all participants.

In this study, dermoscopic images of histopathologically proven benign cutaneous tumors were examined retrospectively and the lesions showing at least a combination of irregular-linear and dotted vessels were detected. The lesions treated with any topical agent prior to excision were excluded. The lesions were collected from outpatient clinics of two centers between 2015 and 2018. Dermoscopic examination was performed using a polarized handheld dermoscope with $\times 10$ magnification (Dermlite 4, 3GEN Inc, San Juan Capistrano, CA, USA). Capture of dermoscopic images was done using a high-resolution mobile camera phone attached to the dermoscope (iPhone 7 plus, Apple Inc, CA, USA). Relationship between two categorical independent variables was evaluated using chi- square test. One way ANOVA test was used to compare the difference between the four groups of a single independent variable. $\mathrm{P}<0.05$ was considered statistically significant. SPSS Windows version 24.0 package software (SPSS Inc., Chicago, IL, U.S.A) was used for statistical analysis.

\section{RESULTS}

A total of 350 histopathologically confirmed benign cutaneous tumors was evaluated regarding

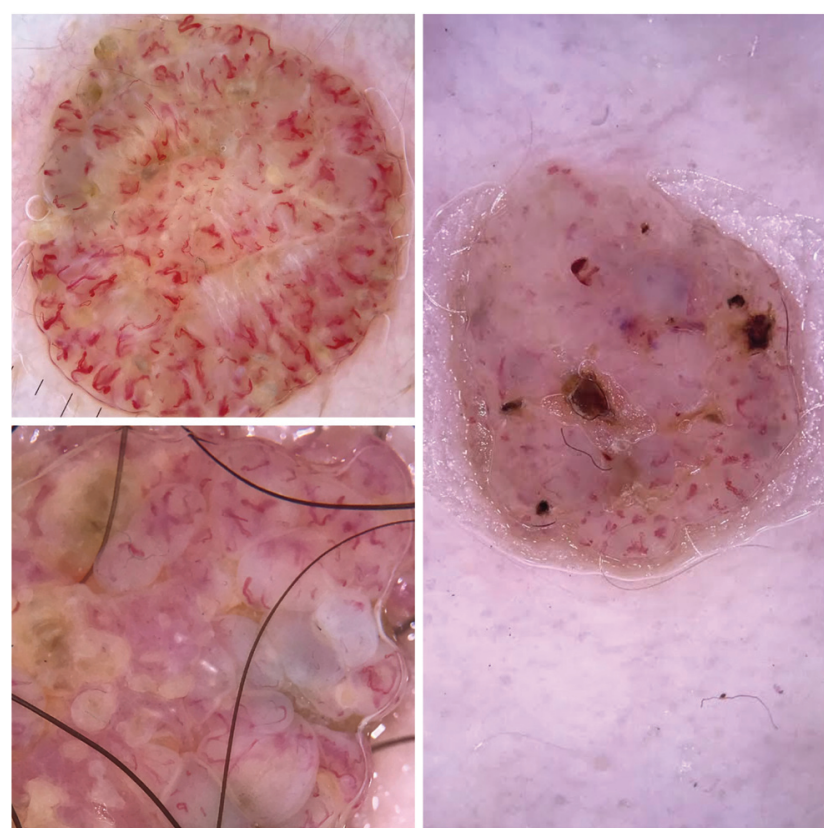

Figure 1. Polymorphous vascular pattern in dermal nevi.

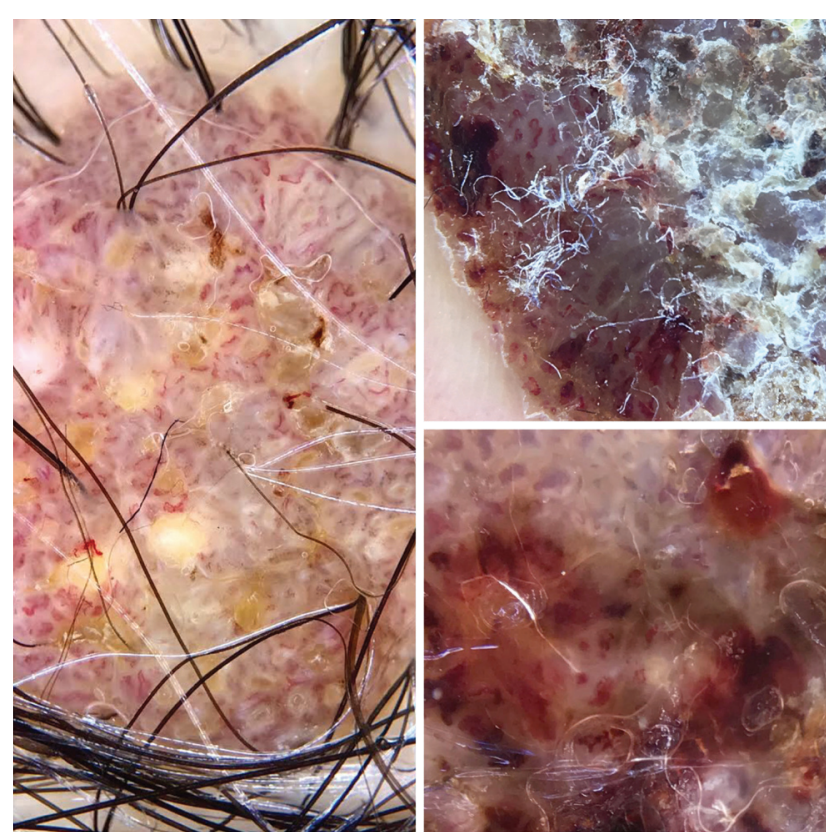

Figure 2. Polymorphous vascular pattern in seborrheic keratoses. 


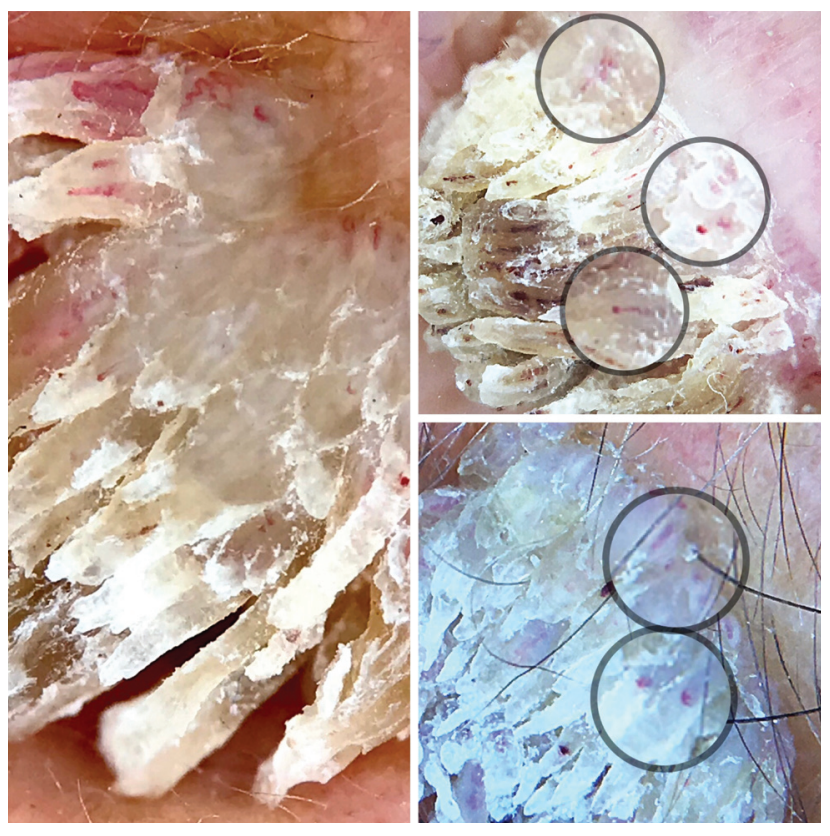

Figure 3. Polymorphous vascular pattern in viral warts.

the presence of PVP. These tumors included dermal/congenital nevi $(n=100)$ (Figure 1), seborrheic keratoses $(n=100)$ (Figure 2$)$, viral warts $(n=100)$ (Figure 3 ) and dermatofibromas $(n=50)$.
Nine percent of dermal/congenital nevi $(n=9)$, $13 \%(n=13)$ of seborrheic keratoses, $5 \%$ of viral warts $(n=5)$ showed PVP. None of the dermatofibromas exhibited this pattern. Presence of PVP in seborrheic keratosis was statistically significant when comparing to nevi $(p<0.05)$, warts $(p<0.05)$ and dermatofibroma $(p<0.01)$.

Demographic and clinical features of the patients are shown in Table 1.

All the vascular patterns observed in each group of the lesions have been demonstrated in Table 2 .

\section{DISCUSSION}

Dermoscopic examination of skin tumors was focused primarily on pigmented structures in the past. Then, gradually, more different structures became the subject of dermoscopic analysis ${ }^{1}$. The arborizing vessels were first described as a useful vascular dermoscopic clue to the diagnosis of basal cell carcinoma ${ }^{3}$. Afterwards, subsequently, se-

Table 1. Demographic and clinical features of the patients.

\begin{tabular}{|c|c|c|c|c|c|c|c|c|c|}
\hline \multirow[b]{2}{*}{ Lesions $(n=350)$} & \multirow[b]{2}{*}{ Mean Age } & \multicolumn{2}{|c|}{ Gender } & \multicolumn{3}{|c|}{ Skin type (Fitzpatrick) } & \multicolumn{3}{|c|}{ Site } \\
\hline & & $\mathbf{M}$ & $\mathbf{F}$ & 2 & 3 & 4 & Head Neck & Trunk & Extremity \\
\hline Dermal nevus $(n=100)$ & 38 & $48 \%$ & $52 \%$ & $4 \%$ & $37 \%$ & $59 \%$ & $\begin{array}{l}54 \% \\
P<0.05\end{array}$ & $21 \%$ & $25 \%$ \\
\hline Seborrheic keratosis $(n=100)$ & $\begin{array}{l}59 \\
P<0.05\end{array}$ & $61 \%$ & $39 \%$ & $3 \%$ & $42 \%$ & $55 \%$ & $38 \%$ & $24 \%$ & $38 \%$ \\
\hline Dermatofibroma $(n=50)$ & 37 & $64 \%$ & $36 \%$ & $2 \%$ & $48 \%$ & $50 \%$ & $2 \%$ & $16 \%$ & $\begin{array}{l}82 \% \\
P<0.05\end{array}$ \\
\hline Viral wart $(\mathrm{n}=100)$ & $\begin{array}{l}26 \\
P<0.05\end{array}$ & $58 \%$ & $41 \%$ & $\begin{array}{l}7 \% \\
P<0.05\end{array}$ & $53 \%$ & $40 \%$ & $17 \%$ & $8 \%$ & $\begin{array}{l}75 \% \\
P<0.05\end{array}$ \\
\hline
\end{tabular}

Table 2. Vascular patterns observed on the dermoscopic examination.

\begin{tabular}{|c|c|c|c|c|c|c|}
\hline Lesions $(\mathrm{n}=350)$ & $\begin{array}{l}\text { Dotted } \\
\text { vessels }\end{array}$ & $\begin{array}{l}\text { Coiled } \\
\text { vessels }\end{array}$ & $\begin{array}{l}\text { Linear } \\
\text { vessels }\end{array}$ & $\begin{array}{l}\text { Curved } \\
\text { vessels }\end{array}$ & $\begin{array}{l}\text { Looped } \\
\text { vessels }\end{array}$ & $\begin{array}{l}\text { Polymorphous } \\
\text { vessels }\end{array}$ \\
\hline Dermal nevus $(n=100)$ & $\% 21$ & $\begin{array}{l}\% 11 \\
\mathrm{P}<0.05\end{array}$ & $\begin{array}{l}\% 13 \\
\mathrm{P}<0.05\end{array}$ & $\begin{array}{l}68 \% \\
P<0.05\end{array}$ & $\% 4$ & $\% 9$ \\
\hline Seborrheic keratosis $(n=100)$ & $\% 14$ & $\% 7$ & $\% 12$ & $\% 18$ & $\begin{array}{l}34 \% \\
\mathrm{P}<0.05\end{array}$ & $\begin{array}{l}\% 13 \\
\mathrm{P}<0.05\end{array}$ \\
\hline Dermatofibroma $(n=50)$ & $\% 8$ & $\% 3$ & $\% 4$ & $\% 4$ & - & - \\
\hline Viral wart $(n=100)$ & $\begin{array}{l}\% 84 \\
P<0.05\end{array}$ & - & $\% 8$ & - & $\% 6$ & $\% 5$ \\
\hline
\end{tabular}


veral types of vessels were suggested for different melanocytic and non-melanocytic skin tumors.

Recently, Kittler et al. have described the dermoscopic structures and vessel patterns using a simple and understandable terminology known as Kittlerian terminology $y^{4,5}$. The vascular patterns mainly included dotted, clotted, looped, curved, serpentine, branched, helical and coiled vessel patterns ${ }^{4,5}$. The characteristic vessel patterns seen in common benign skin growths can be summarized as follows; curved vessels in nevi ${ }^{6}$, looped vessels in seborrheic keratosis ${ }^{7}$, dotted vessels in viral warts ${ }^{8}$ and serpentine (linear-irregular) vessels in pyogenic granuloma?.

PVP has been described as the combination of at least two vascular patterns and histologically may reflect vessels in different sizes and shapes located in superficial papillary dermis ${ }^{4,5}$. A combination of linear-irregular and dotted vessels is usually considered one of the main clues to the diagnosis of melanoma ${ }^{2}$. In the study of Argenziano et al., $20 \%$ of melanomas, $5.1 \%$ of basal cell carcinomas and $21.4 \%$ of squamous cell carcinomas showed PVP ${ }^{1}$. Micantonio et al. ${ }^{10}$ reported PVP in $1.8 \%$ of basal cell carcinomas. In another study investigating dermoscopic features of squamous cell carcinoma, polymorphous vascular pattern was found in $33.3 \%$ of the lesions ${ }^{11}$. PVP was also considered to be one of the main dermoscopic clues to Merkel cell carcinoma ${ }^{12}$. In a web based multicentric study, $2.8 \%$ of nevi and $8.2 \%$ of melanomas demonstrated polymorphous vessel pattern ${ }^{13}$. In the present study, $9 \%$ of dermal nevi exhibited this pattern. In the study of Argenziano et al, 3.2\% of dermal/congenital nevi and $12.2 \%$ of seborrheic keratoses showed PVP ${ }^{1}$. In this study $13 \%$ of seborrheic keratoses demonstrated PVP. Ramyead et al. ${ }^{14}$ also described PVP in a case of clonal seborrheic keratosis.

In this study the frequency of PVP in viral warts was 5 percent. Several studies described the dermoscopic vascular patterns in common warts as dotted, linear, coiled and globular vessels ${ }^{15}$. However, to the best of our knowledge, PVP has not been described previously for viral warts.

In a review in which we investigated the differential diagnosis between pyogenic granuloma and nodular Kaposi's sarcoma based on dermoscopic examination findings, $10 \%$ of the pyogenic granulomas showed PVP, while none of the Kaposi's sarcoma exhibited PVP. In the study of Zaballos et al. ${ }^{9} 13 \%$ of pyogenic granulomas showed PVP. In the same study, the frequencies of PVP in melanoma and basal cell carcinoma were $86 \%$ and $41 \%$, respectively?.

In another study in which we described dermoscopic findings of verrucous epidermal nevi, 15\% of the lesions showed PVP ${ }^{16}$.

Eccrine poroma ${ }^{17}$, clear cell acanthoma ${ }^{18}$ and pilomatrixoma ${ }^{19}$ are other benign skin tumors which may show polymorphous vessels.

\section{CONCLUSION}

To the best of our knowledge, this is the only study primarily focusing on the PVP in benign skin growths. Our study showed that PVP, which is considered to be one of the characteristic findings for malignant skin tumors, is not rare in benign tumors. We suggest that PVP alone should not be accepted as a dermoscopic sign indicating malignancy and should be evaluated in context of the other present structural dermoscopic findings.

\section{REFERENCES}

1. Argenziano G, Zalaudek I, Corona R, et al. Vascular structures in skin tumors: a dermoscopy study. Arch Dermatol. 2004;140:1485-9. [CrossRef]

2. Ayhan E, Ucmak D, Akkurt Z. Vascular structures in dermoscopy. An Bras Dermatol. 2015;904:545-53. [CrossRef]

3. Bahmer FA, Fritsch P, Kreusch J, et al. Terminology in surface microscopy. J Am Acad Dermatol. 1990;23:115962. [CrossRef]

4. Kittler H. Dermatoscopy: Introduction of a new algorithmic method based on pattern analysis for diagnosis of pigmented skin lesions. Dermatopathology: Practical \& 
Conceptual. 2007;13:3.

5. Kittler H, Riedl E, Rosendahl C, Cameron A. Dermatoscopy of unpigmented lesions of the skin: A new classification of vessel morphology based on pattern analysis. Dermatopathology: Practical \& Conceptual. 2008;14:3.

6. Zalaudek I, Kreusch J, Giacomel J, Ferrara G, Catricalà C, Argenziano G. How to diagnose nonpigmented skin tumors: A review of vascular structures seen with dermoscopy. Part I. Melanocytic skin tumors. J Am Acad Dermatol. 2010;63:361-74. [CrossRef]

7. Braun RP, Rabinovitz HS, Krischer J, et al. Dermoscopy of pigmented seborrheic keratosis: a morphological study. Arch Dermatol. 2002;138:1556-60. [CrossRef]

8. Kreusch JF. Vascular patterns in skin tumors. Clin Dermatol. 2002;20:248-54. [CrossRef]

9. Zaballos P, Carulla M, Ozdemir F, et al. Dermoscopy of pyogenic granuloma: a morphological study. $\mathrm{Br} J$ Dermatol. 2010;163:1229-37. [CrossRef]

10. Micantonio T1, Gulia A, Altobelli E, et al. Vascular patterns in basal cell carcinoma. J Eur Acad Dermatol Venereol. 2011;25:358-61. [CrossRef]

11. Rosendahl C, Cameron A, Argenziano G, Zalaudek I, Tschandl P, Kittler H. Dermoscopy of squamous cell carcinoma and keratoacanthoma. Arch Dermatol. 2012;148:1386-92. [CrossRef]
12. Harting MS, Ludgate MW, Fullen DR, et al. Dermatoscopic vascular patterns in cutaneous Merkel cell carcinoma. J Am Acad Dermatol. 2012;66:923-7. [CrossRef]

13. Carrera C, Marchetti MA, Dusza SW, et al. Validity and reliability of dermoscopic criteria used to differentiate nevi from melanoma: a web-based international dermoscopy society study. JAMA Dermatol. 2016;152:798-806. [CrossRef]

14. Ramyead S, Diaz-Cano SJ, Pozo-Garcia L. Dermoscopy of clonal seborrheic keratosis. J Am Acad Dermatol. 2015;73:47-9. [CrossRef]

15. Li X, Yu J, Thomas S, Lee K, Soyer HP. Clinical and dermoscopic features of common warts. J Eur Acad Dermatol Venereol. 2017;31:308-10. [CrossRef]

16. Elmas ÖF, Akdeniz N. Dermoscopic aspect of verrucous epidermal nevi: New findings. Turk J Med Sci (In press) (http://journals.tubitak.gov.tr/medical/accepted.htm).

17. Minagawa A, Koga H. Dermoscopy of pigmented poromas. Dermatology. 2010;221:78-83. [CrossRef]

18. Bugatti L, Filosa G, Broganelli P, Tomasini C. Psoriasis-like dermoscopic pattern of clear cell acanthoma. J Eur Acad Dermatol Venereol. 2003;17:452-5. [CrossRef]

19. Zaballos P, Llambrich A, Puig S, Malvehy J Dermoscopic findings of pilomatricomas.. Dermatology. 2008;217:22530. [CrossRef] 